\title{
Research on the "Trinity" Practical Teaching System of Training Applied Computer Talents
}

\author{
Zijiang Zhu ${ }^{\mathrm{a}^{*}}$ and Yi Hu${ }^{\mathrm{b}}$ \\ South China Business College of Guangdong University of Foreign Studies , Guangzhou 510545, \\ China \\ azzjdwh2002@163.com, ${ }^{\mathrm{b}} 444187113 @ q q . c o m$ \\ * The Corresponding Author
}

Keywords: Computer major; Practical teaching; Trinity; Teaching system

\begin{abstract}
Based on analyzing the current status of constructing practical teaching of computer majors, this paper proposes to construct the trinity practical teaching system for computer majors with the cultivating of students' application abilities as the main line while integrating the three key links in the practical teaching system: teachers, students and resources into practical teaching system so as to constantly optimize the practical teaching system and cultivate students' application ability and practical ability. After years of practice, obvious achievements have been made in this system.
\end{abstract}

\section{Introduction}

At present, higher requirements have been put forward in the society for the quality of computer talents, and employers attach more attention to the talents' ability to solve practical problems and innovation spirit [1]. However, in recent years, there is a contradiction between the employment of graduates of computer-related majors at colleges and universities in China, i.e., enterprises cannot find suitable talents and graduates cannot find suitable jobs [2]. Computer science is a highly practical major that many colleges and universities both in China and abroad have attached great importance to the practical teaching of computer majors and have established various practical teaching systems. They have obtained good effects, but there are still many unsatisfactory situations [3]. Therefore, it is necessary to strengthen the reform and practice of practical teaching system for computer majors.

\section{Analysis of the Present Situation of Practical Teaching for Computer Majors}

Analysis of Practical Teaching at Research Colleges and Universities. The research-oriented colleges and universities in China generally refer to the Project 985 and Project 211 universities, which have few or even no practical teaching links. But these colleges and universities have many scientific research organs and research teams, which can attract students to get involved in scientific research projects so as to train their practical ability and innovative ability. Foreign well-known colleges and universities such as Harvard University's practical teaching system is perfect, provides the high-quality laboratory of science and technology to carry out the practice of practice teaching, undergraduate research plan, project training and other forms of practice teaching system [5]. The university of Oxford in the UK has a long history of the tutorial system and the system of the practice teaching, which has laid a solid foundation for elite talent cultivation.

Analysis of Practical Teaching at Teaching and Research Oriented Colleges and Universities. The task of China's teaching research university is to cultivate undergraduates. The construction of practical teaching system in such colleges is mainly based on laboratory construction. Aimed at cultivating students' innovative ability to cultivate the students' practical ability, only a few outstanding students can through the scientific research project or other forms, such as science and technology competition activities, and get the cultivation of practical ability and innovation ability [6]. Some colleges and universities organize teachers and students to visit enterprises during vacation, experience the enterprise culture and project operation, or students themselves contact the unit to practice, which leads to the practice teaching process only stays on 
the form [7].

Analysis of Practical Teaching at Application Oriented Colleges and Universities. Application-oriented colleges and universities mainly adopt the verification experiment teaching practice, and the teaching system construction is mainly aimed at teaching needs, and it has not reached the level of cultivating students' innovation ability. As a result, many students will not even use the basic office software [8]. Some colleges and universities take the form of cooperation with enterprises or training institutions and send students to these units to participate in project internship or training. However, the internship or training time is short, and there is no complete, systematic and in-depth training, and due to cost and other factors, the effect of this form is not very satisfactory.

Through the above analysis, there are four main reasons for the unsatisfactory construction of practical teaching system in colleges and universities: (1) insufficient investment in practical teaching resources, teaching resources and platform construction have not played a very good supporting role; (2) insufficient emphasis on practical teaching, resulting in insufficient research, lack of systematic construction goals and systems, and poor execution effect; (3) the participation of middle school students is not enough, which leads to the restriction of students' practical ability and innovation ability. (4) there are some misunderstandings in the construction of teaching staff, which leads to the lack of practical teaching ability of many teachers in colleges and universities, which cannot provide beneficial guidance for students. Moreover, if the teachers, students and resources link separated to carry out the construction, not formed a complete and systematic system, will lead to the training effect is not ideal, to this end, we put forward the trinity of computer professional practice teaching system, has carried on the beneficial exploration for the computer professional development.

\section{Trinity Practical Teaching System}

Guangdong University of Foreign Studies South China Business College is an independent college for undergraduates held by Guangdong University of Foreign Studies and approved by the Ministry of Education of China, and it is an application-oriented undergraduate college. The computer science has a good teaching foundation, and the students are of medium scale. Not according to the research university, therefore, construction of practice teaching system, put forward a suitable for our school's practice teaching system of computer professional development, finishing to the students' practice ability and innovation ability training goal. Among them, the trinity refers to teachers, students and resources. One is that the three are not isolated construction targets but are closely linked together to form a complete system [8].

Integrated computer applied talents training practice teaching the core idea is: to practice base, scientific research platform, integration of innovation laboratory, the practice teaching platform and curriculum resource resources construction as the foundation, innovation practice teacher troop and the scientific research team and the enterprise staff construction as the guarantee, the development of the discipline of students education, college students' innovative training program, professional discipline competition, scientific research training plan according to students' practice teaching plan construction as the fundamental, such as all kinds of practical teaching activities, which are organically combined with the students throughout the combination together, and combined with credit system such as system construction, thus forming the integration of many aspects, but the practical teaching system, as shown in Fig. 1. In order to ensure the smooth implementation of the practice teaching system, a series of reform measures should be designed and implemented. 


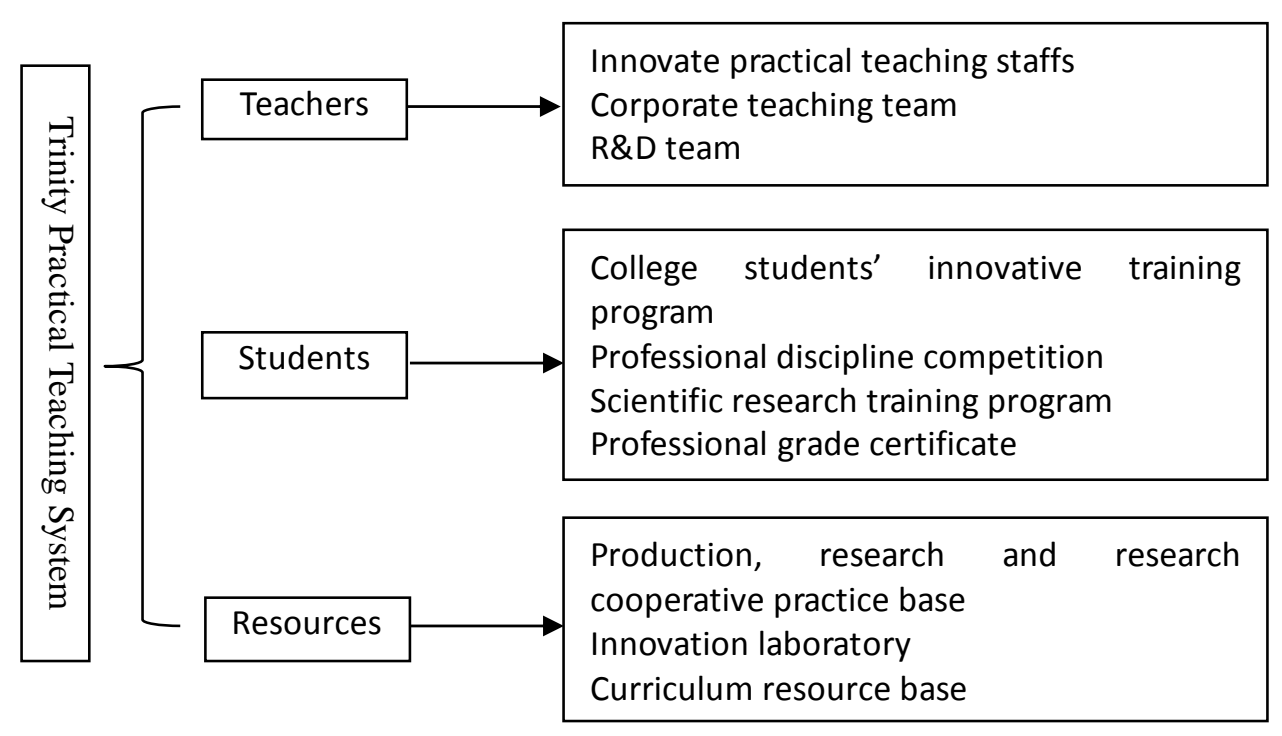

Figure. 1. Trinity Practical Teaching System

Introduction of Modern Teaching Techniques and Means. Applying modern teaching techniques ad means can make the abstract and deep practical theories easy to understand and improve the teaching effect on one hand; on the other hand, Through the use of modern teaching techniques, students are encouraged to love the great superiority of modern science and technology, which can stimulate students' enthusiasm for learning and desire for knowledge. Modern teaching techniques and tools are mainly used in the following areas:

Use multimedia technology and means to carry out practical teaching. The multimedia teaching is applied to the practice teaching of the computer. Through multimedia teaching methods such as voice, animation, image, etc., the complicated abstract computer programming and the complicated operation process are visualized, concrete, simplified and convenient for students to accept. This will not only improve the effectiveness of practical teaching, but also save time, increase the content of classroom teaching and improve the learning effect of students. At present, although some colleges and universities have established multimedia classrooms, they are mainly used in theoretical teaching, and there are few means to use multimedia in practice teaching. If we can use multimedia teaching method in practical teaching so that students can understand the whole process of practice from the courseware demonstration, it will play a very good role in improving the practical teaching effect.

Use LAN, wireless network and online teaching resources. With the establishment of the computer network application environment, the distance between teachers and students can be made closer through the campus and distance and real-time teaching can be realize. Teachers can put the courseware on the curriculum website so that students can search the teachers' experimental instructions at any time. And when they have any questions, they can communicate with the teacher through email, online course forum, QQ and WeChat without talking the empty talk. In addition, through the network, we can consult the methods adopted for the same practice at other colleges and universities, increase the students' access to knowledge, and broaden their knowledge level [9].

Use computers to help practical teaching. Using computer-assisted teaching can overcome space and time limit, make the students preview on the computer at any time, view and practice repeatedly and have hands-on practice, greatly improving the enthusiasm of the students' autonomous learning, cultivate the student' practical ability. If the computer major curriculum practice simulation platform is adopted for practical teaching, it is necessary to make it combine with solving practical problems as much as possible, which cannot only stimulate students' interest but is also conducive to improving students' ability to solve real problems so that students can have the scientific attitude of seeking truth from facts and develop rigorous thinking methods, thus laying a good foundation for future work.

Introduce "class" into multimedia labs. In modern experiment teaching, the constructed labs 
have modern education means, so we might as well introduce "classes" into labs to realize "hand-on" teaching with modern means of education, decompose the difficult knowledge and learn through practice, which is very useful for computer experiment teaching. While listening to and watching the video, students can also operate, which not only consolidates their theoretical knowledge, but also improves students' hand-on ability and organically combine theories and practice so that learning becomes an easy and enjoyable thing.

Establish Open and Innovation Laboratories. Students are the main body of education, and the effect of practical teaching should be realized through the active participation of students. University computer laboratory is not only an important base for practical teaching and cultivation of students' practical ability, but also an important base for cultivating innovative consciousness, professional skills and scientific spirit. However, because many colleges and universities have not sufficient input in computer hardware and software and human resources with backward lab equipment. And students spend little time on the Internet, which makes computer experiments confined to general validation, design and simple operation practice. It is difficult for students to assimilate theoretical knowledge into their own knowledge structure and ability in the limited experimental study. The establishment of open innovation laboratory can not only make up for the shortage of students, but also provide more free space for students to carry out computer experiments and complete the work that cannot be completed in the experimental teaching class. In this process, middle school students can learn independently, think independently and tap their learning potential. At the same time, through their own design module, students can complete the practical project and cultivate innovative awareness and practical ability, so that they can experience the joy of harvest in practice and enhance the confidence of learning.

Increase the Course of Computer Practice and Strengthen the Relationship between Theories and Practical Teaching. Appropriate increase computer practice classes, and theoretical teaching and practice teaching should not be out of line in terms of both class time and schedule. Because of the many teaching contents and tight schedule, teachers often first teach theories and then arrange practical courses. Sometimes, there are only practical courses and when the schooling hours are not enough, there are fewer or no practical courses. Disconnecting the theory class from the practical class is not good for students to deepen the understanding and memory of theoretical knowledge and cannot train students to practice their abilities. Therefore, the application of theoretical and practical lessons should be well connected in terms of time. After the theoretical lessons, it is necessary to practice the lessons in a timely manner and to have adequate arrangements for class hours so as to improve the learning effect.

Theoretical and practical teaching content should not be out of line, because the theoretical teaching is the basis of practical teaching, and practical teaching is under the guidance of the theory. They are closely linked and mutually reinforcing [7].

Organize Students to Participate in Computer Innovative and Scientific Research Projects. Students are the main body of study, and only through a certain amount of scientific training and long-term hands-on practice can they form a strong practical ability. Therefore, the practice instructor should organize students to set up computer innovation interest group to guide students to complete some simple topics. Through the design of the topic and the software development, students are to apply their scattered theoretical knowledge to practice and deepen their understanding of computer-related curriculum and improve students' ability to apply the theories and knowledge. In this way, students can expand their knowledge and cultivate their awareness of participation in practice. On the other hand, they can also cultivate their interest in scientific research and exploration, which helps to cultivate students' innovative awareness and innovative ability.

Write High-Quality Experimental Instructions. Computer theory and technology are currently one of the fastest growing science and technology in the world. Knowledge updates and technology breakthroughs are rapidly changing [10]. Only by changing with the development of the society and the time and preparing high-quality experimental guidebook and making constant modification and adjustment of the experimental course syllabus and outlines for computer majors and constructing 
the "base -comprehensive-design-application" four-level practical teaching system and teaching plan can we adapt to the requirements for talents with the development of computer science. Therefore, the computer practice teaching and management personnel should have timely understanding of the new developments in computer science, formulate a target scientific and rational experimental teaching plan with greater flexibility and operability, revise the syllabus and classify teaching content design so as to suit the actual needs of practical teaching of computer science.

Strengthen the Construction of Practical Computer Major Teachers and Talents. Practical teaching is an important way to develop students' abilities. Teachers should not only have a higher level of professional theory, but also have good practical skills and strong research ability [10] and master advanced computer skills. This requires that colleges and universities should strengthen the construction of teaching staff of practical teaching in computer majors, improve the overall level of practical teaching team, optimize the structure of practical teachers, strengthen the training of practical teaching teachers and improve the treatment of practicing teachers, so as to form a team of and stable teaching staffs with strong professionalism, rational structure for computer majors to improve the quality of computer teaching practice.

Establish and Improve the Practical Teaching Comprehensive Management System. Practical teaching management is a multi-factor, multi-level and multi-objective structural system. Because it has many particularities and relatively many management links, it brings many difficulties to management and comprehensive evaluation. It is necessary to establish a scientific and comprehensive practical teaching comprehensive system to guarantee the evaluation and training quality of practice teaching. Therefore, a systematic management and evaluation method should be established according to the characteristics of the practice teaching of computer majors. From the practice of teaching plan preparation, teaching schedule arrangements, to the student experimental preview report, the conclusion of the experimental conclusion report, there should be detailed assessment, supervision and evaluation methods.

\section{Conclusion}

After many years of hard work, our school has initially established relevant practical teaching systems for computer related majors and has formulated corresponding policies and laboratory teaching management systems. Through years of practice, the employment rate of computer graduates in our school has been improved to a certain extent. The number of students recruited by relevant key industries and enterprises has also been increasing year by year, which shows that the implementation of the trinity system practical teaching system has achieved good teaching results. And students' hands-on ability and innovative ability have been significantly improved.

\section{Acknowledgements}

This paper is supported by the Model Demonstration of computer science and technology applied talents training, South China Business College of Guangdong University of Foreign Studies-Guangzhou Xinbao Software Technology Co., Ltd. Out-of-school Practice Teaching Base for Undergraduates in Guangdong Province (Teaching Quality and Teaching Reform Project of Guangdong Province in 2015 for the undergraduate education (Guangdong Education Letter 2015 [133])).

\section{References}

[1] S.B. Wang and H.X. Xi: Higher Engineering Education Research, Vol. 1(2011) No.1, p.19-23.

[2] G.P. Jiang and X. Shi: Laboratory Research and Exploration, Vol.29 (2010) No.4, p.66-69.

[3] F.Y. Xu and M.X. Huang: Electrification Education Research, Vol.1 (2013) No.10, p.39-42.

[4] X.S. Cheng and Y.J. Xu: Laboratory Science, Vol.13 (2010) No.1, p.186-188.

[5] X.M. Wang: Experimental Technology and Management, Vol.30 (2013) No.2, p.1-4. 
[6] L.C. Dfaz and A.M. Algorry A M: IEEE Latin America Transactions, Vol.11 (2013) No.1, p.591-595.

[7] J.Q. Du and Q. Ye: Computer Education, Vol.10 (2011) No.20, p.29-31.

[8] K.X. Wei and Y.C. Liu: China's University Teaching, Vol.1 (2011) No.1, p.74-76.

[9] J. Wang and X.H. Wang: Computer Knowledge and Technology, Vol.7 (2016) No.6, p.1363-1365.

[10] Y.L. Zhou and X.B. Li: Education and Occupation, Vol.1 (2017) No.2, p.34-35. 